UDC 631.349 .2

LBC 44.9

\title{
OXIDATIVE STRESS OF PLANTS: CHEMISTRY, PHYSIOLOGY, METHODS OF PROTECTION
}

\author{
Ekaterina V. Khozeeva \\ Volgograd State University, Volgograd, Russian Federation \\ Yuliya A. Zimina \\ Volgograd State University, Volgograd, Russian Federation \\ Galina A. Sroslova \\ Volgograd State University, Volgograd, Russian Federation
}

\begin{abstract}
Under conditions of biotic and abiotic stress, reactive oxygen species (ROS) are formed in plants, which causes oxidative stress. At the same time, ROS play additional signaling roles in plant adaptation to stress. The study of the mechanisms of this process makes it possible to develop new ways of protecting organisms, in particular, agricultural plants, from negative stress effects. This review describes the current understanding of oxidative stress the process of inhibition of the vital activity of cells under the action of reactive oxygen species. The distinctive features of plant oxidative stress and two main pathways of metabolic protection - the jasmonate and salicylate pathways - are separately identified. Various ways of identifying oxidative stress are also given. Innovative methods of protecting agricultural plants from oxidative stress are considered: the use of biopesticides - rhizobacteria and microscopic fungi, elicitors - the youngest direction in creating effective methods of protection. It also describes a relatively outdated method of protection - the use of fungicides. These substances were included in the review due to the recent appearance of biodegradable preparations of this type. Special attention is paid to elicitors - substances that are not typical for plants, the appearance of which in the cell causes a chain of biochemical processes similar to the metabolism of plants under oxidative stress. The most studied substances with the properties of elicitors are described: salicylic acid, jasmonates, hytosan and hydrogen peroxide; their role in the chain of response reactions. As an alternative, isothiocyanates - the main components of the "mustard bomb" - the protective mechanism of plants of the cruciferous family are considered. Also, the latest studies of isothiocyanates in the metabolic processes of plants are described.

Key words: oxidative stress, elicitors, salicylic acid, isothiocyanates, plant protection, agricultural plants.

Citation. Khozeeva E.V., Zimina Yu.A., Sroslova G.A. Oxidative Stress of Plants: Chemistry, Physiology, Methods of Protection. Natural Systems and Resources, 2020, vol. 10, no. 4, pp. 30-43. DOI: https://doi.org/ 10.15688/nsr.jvolsu.2020.4.4

УДК 631.349 .2

ББК 44.9

\section{ОКИСЛИТЕЛЬНЫЙ СТРЕСС РАСТЕНИЙ: ХИМИЯ, ФИЗИОЛОГИЯ, СПОСОБЫ ЗАЩИТЫ}

Екатерина Владимировна Хозеева

Волгоградский государственный университет, г. Волгоград, Российская Федерация

Юлия Александровна Зимина

Волгоградский государственный университет, г. Волгоград, Российская Федерация

Галина Алексеевна Срослова

Волгоградский государственный университет, г. Волгоград, Российская Федерация 
Аннотация. В условиях биотического и абиотического стресса в растениях образуются активные формы кислорода (АФК), вызывающие окислительный стресс. В то же время АФК выполняют дополнительные сигнальные роли в адаптации растений к стрессу. Изучение механизмов этого процесса позволяет разработать новые способы защиты организмов, в частности, сельскохозяйственных растений, от негативного стрессового воздействия. В данном обзоре описаны современные представления об окислительном стрессе - процессе угнетения жизнедеятельности клеток под действием активных форм кислорода. Отдельно выделены отличительные черты окислительного стресса растений и два основных пути метаболической защиты - жасмонатный и салицилатный путь. Также приведены различные способы идентификации окислительного стресса. Рассмотрены инновационные способы защиты сельскохозяйственных растений от окислительного стресса: применение биопестицидов - ризобактерий и микроскопических грибов, элиситоры - наиболее молодое направление в создании эффективных способов защиты. Также приведено описание относительно устаревшего способа защиты - применение фунгицидов. Данные вещества вошли в обзор по причине недавнего появления биоразлагаемых препаратов данного типа. Отдельное внимание уделено элиситорам - веществам, нехарактерным для растений, появление которых в клетке вызывает цепь биохимических процессов, подобных метаболизму растений в условиях окислительного стресса. Описаны наиболее изученные вещества со свойствами элиситоров: салициловая кислота, жасмонаты, хитозан и перекись водорода; их роль в цепи ответных реакций. Как альтернатива рассмотрены изотиоцианаты - основные компоненты «горчичной бомбы» - защитного механизма растений семейства крестоцветных. Также описаны новейшие исследования изотиоцианатов в метаболических процессах растений.

Ключевые слова: окислительный стресс, элиситоры, салициловая кислота, изотиоцианаты, защита растений, сельскохозяйственные растения.

Цитирование. Хозеева Е. В., Зимина Ю. А., Срослова Г. А. Окислительный стресс растений: химия, физиология, способы защиты // Природные системы и ресурсы. - 2020. - Т. 10, № 4. - С. 30-43. - DOI: https:// doi.org/10.15688/nsr.jvolsu.2020.4.4

\section{Введение}

Воздействие различных факторов окружающей среды, таких как засоленность, засуха, тяжелые металлов, экстремальные температуры, ультрафиолетовое излучение, пестициды и инфекция патогенными микроорганизмами, приводит к окислительному стрессу у растений, который, в свою очередь, влияет на биологические процессы посредством образования АФК $[22 ; 38]$. АФК включают гидроксильные радикалы, синглетный кислород и пероксид водорода в клетках растений и активируют сигнальные пути, приводящие к некоторым изменениям физиологических, биохимических и молекулярных механизмов клеточного метаболизма [23; 36; 42]. Однако, чрезмерное количество АФК вызывает окислительный стресс, состояние дисбаланса между производством АФК и нейтрализацией свободных радикалов антиоксидантами, что приводит к повреждению клеточных компонентов, включая липиды, нуклеиновые кислоты, метаболиты и белки, что в конечном итоге приводит к гибели клеток растений $[5 ; 27]$.
Чтобы улучшить устойчивость растений к суровым условиям окружающей среды, жизненно важно иметь четкое понимание механизма окислительного стресса и антиоксидантных систем. Таким образом, необходима систематизация новых знаний и научных достижений в данной области.

Также следует отметить, что факторы, вызывающие окислительный стресс неуклонно усиливаются в следствие техногенного воздействия на окружающую среду (засоление и загрязнение почв, изменение климата и др.). Поэтому для развития сельского хозяйства в современных агроэкономических условиях перспективно и весьма актуально внедрение экологически безопасных технологий. Выходом из сложившейся ситуации может служить создание методов повышения устойчивости растений к стрессам с использованием безопасных для окружающей среды компонентов и технологий. В связи с этим, в данный обзоре представлены с одной стороны, современные представления о механизмах окислительного стресса, с другой - основные методы защиты растений от него. 


\section{ЭКОЛОГИя И БИОЛОГИЯ}

\section{Современные представления о механизме окислительного стресса}

Для поиска путей защиты организмов от окислительного стресса необходимо понимание механизмов процессов, которые протекают при этом в клетках.

Окислительный стресс - это процесс, возникающий в результате повышенной концентрации активных форм кислорода (АФК) в клетках организма и является ключевым компонентом реакций организма на стрессовые условия среды и имеет сложный и разнообразный метаболизм [28; 37$]$.

Дисбаланс в уровне генерации и нейтрализации АФК, часто является следствием несостоятельности антиоксидантных систем организма. Свободные радикалы, чаще всего представленные АФК, - это молекулы с высокой реакционной способностью, имеющие неспаренные электроны. Помимо кислорода, такие молекулы могут образовывать также атомы азота и серы [23].

Самые распространенные активные формы кислорода - это супероксид - анион-радикал $\mathrm{O}_{2}^{-}$, гидроксильный радикал $\mathrm{OH}^{-}$, пероксинитрит $\mathrm{ONOO}^{-}$. Из-за своей высокой реакционной способности пероксид водорода $\mathrm{H}_{2} \mathrm{O}_{2}$ также относится к АФК, хоть и не является радикалом [28; 36].

Окислительный стресс приводит к ряду негативных эффектов, среди которых наиболее распространены изменения клеточных структур, нарушение активности цитозольных и митохондриальных ферментов, истощение антиоксидантных защитных систем, изменение состава метаболитов и некоторые другие изменения. К следствиям такого разрушительного воздействия АФК относятся перекисное окисление липидов и фосфолипидов клеточных мембран, окислительное повреждение белков (например, по остаткам тирозина, цистеина и серина), Fe-центры ферментов, фрагментация пептидных цепей (повышает чувствительность белков к действию протеаз), повреждение клеточной и митохондриальной ДНК, снижение активности антиоксидантов клетки изза окисления глутатиона и НАД(Ф) $\mathrm{H}_{2}$. Реактивные производные кислорода могут взаимодействовать с нуклеиновыми кислотами, повреждая азотистые основания, дезоксири- бозы и рибозы. Модификация азотистых оснований приводит к разрывам водородных связей между цепями ДНК и повреждению хромосом [36].

Таким образом, основным регулятором уровня АФК в клетке является содержание кислорода. При взаимодействии кислородных радикалов с ненасыщенными жирными кислотами, входящими в состав мембранных липидов, запускается процесс перекисного окисления липидов. При этом кислородный радикал отнимает атом водорода из молекулы жирной кислоты, после чего образуется новый перекисный радикал. Радикал жирной кислоты может взаимодействовать с другой органической кислотой, распадаясь на два новых радикала, каждый из которых запускает новую последовательность радикального окисления. То есть, происходит амплификация окислительного повреждения, реакция имеет цепной характер и может затрагивать значительное количество клеточных липидов [28; 42].

Одним из главных генераторов АФК в клетке являются пероксисомы, содержащие целый ряд ферментов, связанных с метаболизмом пероксида водорода. Пероксид водорода используется клеткой в основном для обезвреживания потенциально опасных агентов, и практически вся утилизируется в этих же органеллах. Источником супероксид-анионов в клетке является гладкий эндоплазматический ретикулум, в котором локализован ряд цитохром-зависимых оксигеназ, продуцирующих данный радикал.

Основной источник активных форм кислорода в клетках являются дыхательные цепи митохондрий и пластид. Это объясняется тем, что в дыхательной цепи происходит «утечка» электронов с ферментных комплексов, за счет чего около некоторая часть поступающего кислорода переходит в активную форму, при этом часть АФК идет на окислительную модификацию макромолекул [17].

К основным ферментам-антиоксидантам клеточных защитных систем относятся супероксиддисмутазы, каталаза и пероксидазы. Глутатион и тиоредоксин относятся к веществам, обеспечивающим окислительно-восстановительный буфер клетки. Глутатион обеспечивает поддержание редокс-состояния 
клетки за счет нейтрализации перекиси глутатионпероксидазой с последующим восстановлением окисленного глутатиона до глутатиона глутатионредуктазой с использованием НАДФН ${ }^{+}[3 ; 15]$.

Супероксиддисмутазы катализируют реакцию образования пероксида водорода и триплетного кислорода из суперокидного анион-радикала, тем самым лимитируя процессы превращения супероксидного радикала в другие активные формы кислорода. Этот фермент представлен несколькими изоформами, которые находятся во всех клеточных компартментах, где возможно образование супероксида. Супероксиддисмутазы катализируют дисмутацию двух атомов супероксида с образованием пероксида водорода и кислорода. Таким образом осуществляется поддержание постоянного уровня кислорода во всей клетке [4].

Пероксид водорода, образующаяся при дисмутации супероксида, нейтрализуется либо другими пероксидами, либо ферментом каталазой. Каталаза разлагает пероксид до воды, однако этот фермент в основном активен в пероксисомах, поэтому в других частях клетки пероксид водорода чаще всего нейтрализуется глутатионпероксидазой [3; 15].

\section{Особенности окислительного стресса растений}

Наиболее ранняя реакция растительного организма на внедрение потенциально опасного агента - генерация активных форм кислорода (окислительный взрыв), запускающих цепь последующих защитных реакций [31].

Несмотря на то, что существует множество опасных для растений веществ, для каждого из которых имеется свой механизм распознавания, общим для них является совокупность реакций фосфорилирования, в результате которых остаток фосфорной кислоты передается на внутренний участок рецептора, активируя ассоциированный с рецептором фермент. Наружный N-конец рецептора специфичен к патогену, а внутренний С-конец - к ассоциированному с рецептором ферменту, определяющему, с какой из двух сигнальных систем будет осуществляться взаимодействие. Возможны два сигнальных пути: жасмонатный и салицилатный [7; 35].
Жасмонатный сигнальный путь характерен для некротрофных патогенов - агентов, умерщвляющих растение или часть растения, и питающихся его отмершими частями. Предполагается, что жасмонаты усиливают активность защитных систем растительного организма, будучи интегральной частью системы передачи сигнала. Заражение растений патогенной флорой сопровождается выделением газообразного гормона этилена, играющего значительную роль в повышении их резистентности [35].

Другой - салицилатный путь - характерен для биотрофных патогенов, то есть, для патогенов, поражающих живые растения (без умерщвления). В процессе салицилатного сигнального пути участвует посредник - салициловая кислота, которая также является стрессовым фитогормоном [7; 10].

В процессе защитных реакций, вызванных действием патогенов, образуются активные формы кислорода, которые негативно действуют на патоген вплоть до аномалий развития патогена [2].

Условия окислительного стресса, сравнимые с действием высоких концентраций экзогенного пероксида водорода, достоверно увеличивают содержание салициловой, сиреневой, ванилиновой и коричной кислот по сравнению с контрольными значениями этого показателя. Так же, увеличение концентрации салициловой кислоты наблюдается при добавлении в среду культивирования различных концентраций генераторов супероксидных радикалов $[7 ; 10 ; 35]$.

Имеются данные, указывающие на то, что при заражении патогенами содержание салициловой кислоты в клетках растений резко повышается. Полагают, что экзогенная салициловая кислота повышает устойчивость растительного организма к инфекции, увеличивая содержание перекиси водорода. Также установлено, что добавление салициловой кислоты в среду культивирования приводит к достоверному повышению концентрации перекиси водорода в культивируемых клетках растений. Согласно, имеющимся в литературе сведениям салициловая кислота действует на каталазу ингибирующе, связывая ее. Далее, в результате подавления активности каталазы нарушается механизм 


\section{ЭКОЛОГИя И БИОЛОГИЯ}

основного расщепления перекиси водорода, что приводит к ее накоплению. Это приводит не только к интоксикации патогенов, но и к целому комплексу важнейших ответных реакций для развития иммунитета у растений $[7 ; 10 ; 35]$.

\section{Факторы, вызывающие окислительный стресс растений}

Известны различные классификации факторов, вызывающих стресс. Их можно разделить на физические (высокая и низкая температура, влажность, радиация, механические воздействия) химические (соли, тяжелые металлы, пестициды) и биологические (возбудители болезней: вирусы, грибы, бактерии).

Распространенным стрессовым фактором для растений является избыток тяжелых металлов в почве. Присутствие тяжелых металлов вызывает нарушения роста и развития растений, способствует повреждению липидных мембран, белков и нуклеиновых кислот в клетках, и, в итоге, приводит к повышению образования АФК и, что приводит к окислительному стрессу. Такие изменения ведут к усилению активности защитных систем у растительного организма [38].

Реакция растений на действие тяжелых металлов носит неспецифичный характер. Металлы попадают в ткани растений через поглощающую систему корней вместе с ионами, необходимыми для минерального питания [5]. Загрязнение тяжелыми металлами очень опасно, так как даже при слабом загрязнении они накапливаются в растениях больше нормы. Реакцией на такое загрязнение является скручивание листьев, недоразвитость корней, красноватость жилок и черешков; тормозятся процессы фотосинтеза (подавляется образование антоциана и других пигментов), транспирации, фиксации $\mathrm{CO}_{2}$; изменяется проницаемость мембран.

Связь между накоплением ионов металлов в растении имеет доказанную связь с увеличением содержания АФК в клетках [5].

Также часто встречающееся условие, которое вызывает окислительный стресс - это засоление почв. Отмечается, что характерным проявлением окислительного стресса вследствие засоленности почв является по- вышение редокс-активности экстрактов листьев. Влияние данного фактора наиболее изучено исследователями [16; 42].

Выделяют следующие типы засоления по содержанию анионов в почве: хлоридное, сульфатное, хлоридно-сульфатные и карбонатное. Считается, что наиболее опасно для растений засоление, вызванное избыточным содержанием карбоната натрия, поскольку в присутствии воды в почве данная соль подвергается частичному гидролизу, образуя слабощелочную среду, что является дополнительным стрессовым фактором для растений $[1 ; 40]$.

При изучении действия на растения отрицательных температур было отмечено, что дополнительной причиной усиления образования АФК может быть нарушение функций биомакромолекул и мембранных комплексов вследствие обезвоживания, обусловленного образованием внеклеточного льда [27].

\section{Индикация окислительного стресса}

В исследованиях, посвященных поиску новых методов защиты растений от окислительного стресса возникает необходимость в индикации этого процесса, то есть в установлении ответной реакции организма на стрессовое воздействие.

С помощью различных методов можно оценить уровень окислительного стресса в разных его проявлениях: концентрация и выраженность разных видов активных форм кислорода; окислительное повреждение биомолекул; активность антиоксидантных ферментов.

В модельных опытах можно определить массу и высоту надземной части растений, среднюю площадь листовой пластинки в 20-30-кратной повторности. Общую антиоксидантную активность возможно установить в экстрактах из смешенных растительных проб в 3-кратной повторности [16; 29].

Для регистрации синтеза супероксиданиона $\mathrm{O}_{2}{ }^{-}$применяют реакцию восстановления цитохрома $\mathrm{C}$, при которой феррицитохром с восстанавливается до ферроцитохрома С с изменением поглощения при 550 нм. Можно также использовать более простой метод НСТ-тест, основанный на реакции восстановления красителя нитросинего тетразолия до диформазана, образование которого легко ре- 
гистрируется спектрофотометром по поглощению при 550-560 нм.

Регистрация пероксида водорода может осуществляться спектрофотометрически по поглощению при 240 нм, амперометрически с помощью специально разработанных биосенсоров для $\mathrm{H}_{2} \mathrm{O}_{2}$, полярографически по образованию $\mathrm{O}_{2}$ при разложении каталазой, спектрофото- и спектрофлуорометрически по образованию окрашенных продуктов в реакциях окисления доноров протонов в присутствии пероксидазы хрена. На способности перекиси водорода окислять ионы $\mathrm{Fe}^{2+}$ в реакции Фентона основан спектрофотометрический метод $\mathrm{FOX}$ : образующиеся ионы $\mathrm{Fe}^{3+}$ взаимодействуют с ксиленолом оранжевым, который превращается в пурпурно-голубой комплекс с максимумом поглощения при 560 нм.

Несмотря на наличие систем репарации, возможно идентифицировать окисленные биомолекулы.

Окислительные повреждения белков и аминокислот регистрируют с помощью высокочувствительных масс-спектрометров с использованием матрично-активированной лазерной десорбции или ионизации (MALDI) или ионизацией распылением в электрическом поле (ESI) [41]. Отдельно возможно применение изотопных аффинных меток (ICAT) для идентификации любых видов обратимого окисления остатков цистеина [32].

Упомянутые методы можно использовать и для определения продуктов окисления липидов и модификаций липопротеинов. Как альтернативу можно зарегистрировать данные соединения путем определения содержания изо- и нейропростанов, пропеналей (акролеин), 2-гидрокси-4-ноненаля, лизофосфатидилхолина, оксистеринов (кето- и гидроксипроизводных холестерина), липофусцина.

Результатом окислительного повреждения основных фосфолипидов цитоплазматической мембраны является 2-хлорапидовая кислота. Оценка ее количества с помощью масс-спектрометрии может служить маркером галогенирующего окислительного стресca. К числу интегральных показателей окислительного повреждения в организме можно отнести выявление в тканях и плазме крови окисленных липопротеинов, эффективно опре- деляемых иммуноферментным анализом или УФ-спектрофотометрией по накоплению липогидропероксидов при 233 нм [14].

Определить активность каталазы можно с помощью спектрофотометрического метода, основанного на определении скорости разложения пероксида водорода каталазой исследуемого образца с образованием воды и кислорода [13].

Общую активность супероксиддисмутазы определют по способности фермента ингибировать фотохимическое восстановление нитросинего тетразолия.

\section{Современные методы защиты растений от окислительного стресса}

В настоящее время уделяется все большее внимание состоянию окружающей среды. Высокая биологическая активность при малых уровнях воздействия, способность к циркуляции в окружающей среде и возможность контакта с ними населения - это характерные особенности, определяющие опасность пестицидов для человека и среды его обитания. Именно поэтому агрономические хозяйства постепенно переходят на более безопасные методы обработки растений.

На рынках мира стали появляться препараты нового поколения, отличающиеся тем, что не проявляют токсичности, не оказывают губительного влияния на экологическую систему и безопасны для человека. Некоторые из них являются микробиологическими препаратами, а некоторые - химически синтезированными [21].

Фунгициды. Для защиты семян и всходов от поражения фитопатогенными грибами, находящимися на семени и обитающими в почве, применяется обработка семян фунгицидами - протравливание. Протравливание имеет много преимуществ перед другими способами применения фунгицидов. Например, в отличие от опрыскивания, фунгицид наносится только в место, которое подвержено заражению, из-за чего потери действующего вещества минимальны. Это обеспечивает интенсивную защиту от болезней на ранних стадиях развития растений. Также, в процессе роста растения фунгицид быстро разлагается в почве, не нанося вреда другим организ- 


\section{ЭкоЛОГИЯ И БИоЛОГИя}

мам, то есть, вещество действует исключительно во время прорастания семени, когда растение больше всего подвержено патогенам. Единственная сложность в работе с фунгицидами - это необходимость при выборе препарата учитывать видовой состав возбудителей - патогены, которым подвержено растение, степень зараженности семян, спектр действия самого препарата, фитосанитарной обстановки предыдущих сезонов, а также степени устойчивости сорта к болезням [8].

Однако, стоит учитывать, что рентабельность применения фунгицидов относительно мала по причине недостатка информации при выборе фунгицида - для правильного назначения данных препаратов требуется большое количество информации.

Фунгициды подразделяют на следующие химические классы, в зависимости от строения действующего вещества.

Азолы - это фунгициды защитного, а также лечебного действия. Они подавляют грибы, корневые гнили. Их применяют для обработки семян, как протравители. К азоламотносятся бензимедазолы, триазолы, имидазолы.

Бензимедазолы используют против церкоспорилиозной гнили, снежной плесени, мучнистой росы, фузариозной гнили, аскохитоза, ризоктониоза, фомоза, антракноза. При многократном использовании этого действующего вещества у болезней может появиться резистентность. Действующими веществами этих фунгицидов являются карбендазим, фуберидазол, тиофанатметил, беномил.

Триазолы проявляют высокую эффективность против мучнистой росы, ржавчины и различных пятнистостей листьев. Триазол, проникая в фитопатогенные грибы, вызывает нарушение их роста, что, в конечном счете, приводит к их гибели. В связи с тем, что все триазолы ингибируют только один специфический фермент, у фитопатогенов возможно возникновение устойчивости к ним [20].

Для того, чтобы у болезней не возникла резистентность против триазолов, необходимо избегать многократных обработок триазолом без использования фунгицидов с другими механизмами действия, особенно в случае сильного распространения болезни. Чередовать обработки триазола с фунгицидами других механизмов действия и использо- вать их баковые смеси. Использовать триазол точно по инструкции производителя (соответствующие болезни и фазы развития растения). Некоторые триазолы наиболее высокоэффективны на ранних стадиях развития болезни [12].

Полезные почвенные микроорганизмы (биопестициды). Полезные почвенные микроорганизмы представлены двумя группами - ризобактерии и грибы PGPR (ризобактерии) и PGPF (грибы).

На рынке имеются культуры спорообразующих бактерий с широким спектром действия: с энтомоциднымии антагонистическими свойствами, с фитозащитным и ростстимулирующим действием, со способностью подавлять патогены растений и животных [9].

С недавнего времени представителей ризобактерий активно используют в борьбе с вредителями растений, а также в качестве удобрений.

Основные преимущества почвенных микроорганизмов заключаются в экологической чистоте (их использование способствует самоочищению почвы), стабильной защите от фитопатогенов (замедляет или прекращает развитие фитопатогенных микроорганизмов), снижении окислительного и токсического стресса, улучшении питания корней (улучшает азотное и фосфорное питание), а вместе эти факторы выражаются в стимуляции роста и продуктивности растений.

В промышленных мастабах используют следующие роды бактерий: Agrobacterium, Azoarcus, Azospirillum, Rhizobium, Azotobacter, Arthrobacter, Bacillus, Clostridium, Enterobacter, Gluconoacetobacter, Pseudomonas и Serratia. Среди наиболее часто применяемых в Российской Федерации микроорганизмов - ризобактерия Agrobacterium radiobacter. Этот препарат эффективен на зерновых, овощных и кормовых культурах в лабораторных и полевых условиях в открытом и защищенном грунте [18].

На данный момент на Российском рынке наиболее востребованы следующие препараты:

- «Бацитурин» обеспечивает снижение численности вредителей овощных культур и картофеля - паутинного клеща, морковной листоблошки, колорадского жука на 82-96 \%. $\mathrm{B}$ сравнении с широко применяемыми для за- 
щиты картофеля химическими средствами препарат отличается выраженным последействием на популяцию колорадского жука, тем самым обеспечивая снижение численности вредителя в следующем поколении. Бацитурин безвреден в отношении полезных насекомых, что в совокупности с высокой эффективностью подтверждает целесообразность его производства и применения;

- «Фитопротектин» предназначен для борьбы с грибными и бактериальными болезнями овощных культур - слизистым и сосудистым бактериозами, альтернариозом, бурой пятнистостью. Снижает заболеваемость растений на 30-60 \%, повышает урожайность на 20-30 \%, стимулирует прорастание семян и развитие растений, способствует получению экологически чистой продукции;

- «Бетапротектин» применяется для защиты сахарной свеклы от кагатной гнили при хранении, обеспечивает снижение вредоносности и степени развития заболевания на 50 и $64 \%$ соответственно;

- «Экогрин» используется для защиты овощных и зеленных культур от болезней в условиях малообъемной гидропоники. Его применение сдерживает распространение и развитие серой гнили огурца в среднем на 15,3\% и снижает пораженность плодов на 51,8 \% [9].

Элиситоры. Элиситорами называют вещества, не свойственные для растительных клеток, вызывающие стресс разной степени выраженности, при этом запускаются метаболические пути защиты. Растения реагируют на инородные вещества, активируя ряд механизмов, подобных защитным реакциям на патогенные инфекции или раздражители окружающей среды, что усиливает синтез соответствующих химических веществ. Часто элиситорами являются молекулы биологического происхождения, которые взаимодействуют с растениями во время грибковых, бактериальных, вирусных или травоядных инфекций (экзогенные элиситоры), а в некоторых случаях высвобождаются из атакованного растения под действием ферментов возбудителя (эндогенные элиситоры) [24].

Салициловая кислота и жасмонаты (жасмоновая кислота, метилжасмонат) вызывают экспрессию генов растений для различных биосинтетических путей, поэтому часто оп- ределяются как «гормоны», поскольку они индуцируют клеточный ответы при низких концентрациях, удаленных от места их синтеза, и могут применяться к растениям различными способами [1]. Например, метилжасмонат можно наносить на растения в виде газа в замкнутой среде, в жидкой форме для гидропонного раствора или с помощью спреев с жасмонатом. Обработка молодых плодов красной и черной малины жасмонатами приводила к увеличению в ягодах антоцианов и фенольных соединений. Было установлено, что низкие концентрации салициловой кислоты приводят к снижению активности каталазы, однако более высокие ее концентрации не вызывают достоверных изменений уровня активности фермента [25].

Существуют сведения о влиянии экзогенной аскорбиновой кислоты на растения пшеницы подвергнутой воздействию повышенной концентрации тяжелых металлов, которые вызывали снижение ростовых параметров, способствовали резкому ухудшению энергетического баланса и развитию окислительного стресса. Выяснилось, что аскорбиновая кислота оказывает защитный эффект, выражающийся в повышении значений морфометрических показателей, стабилизации энергетического баланса и уменьшении перекисного окисления липидов [5].

Также, одним из наиболее исследованных элиситоров является хитозан - биогенный гетерополимер К-ацетилглюкозамина и глюкозамина. Основные патогены растений грибы - часто содержат в своих клеточных стенках хитин. Так как клеточная стенка грибов при заражении взаимодействует со специфическими рецепторами в цитоплазматической мембране растительных клеток, хитозан является элиситором. То есть, распознавая хитозан, растения получают химический сигнал о близости патогена и запускают защитные метаболические пути. Хитозан проявляет антибактериальную и антигрибковую активности, способен стимулировать иммунную систему посредством активации макрофагов, фибробластов, системы комплемента, активации миграции полиморфноядерных лейкоцитов. Хитоолигомеры вовлечены в биосинтез гиалуроновой кислоты и обладают морфогенетической активностью у позвоночных. 


\section{ЭкоЛОГИЯ И БИоЛОГИя}

Хитозан может быть использован как адьювант или радиопротектор. В качестве элиситора повышает устойчивость растений к грибным и вирусным заболеваниям [6; 18]. Таким образом, элиситорные способности хитозана обусловлены как специфическим связыванием остатков К-ацетилглюкозамина с рецепторами на поверхности растительных клеток, так и неспецифическим взаимодействием остатков глюкозамина за счет свободных аминогрупп с внешними и внутренними клеточными компонентами. Такое многогранное действие хитозана - специфическое и неспецифическое - на внешние и внутренние структуры клетки, может позволить растению более надежно фиксировать хитозановый сигнал и включать защитные реакции с разными механизмами запуска и действия [6;18]. В связи с этим широко исследуются возможности повышения эффективности получения хитозана с целью применения его в различных областях $[11 ; 19]$.

Среди элиситеров различного происхождения особый интерес представляют изотиоцианаты, которые легко могут быть получены из растительного сырья, произрастающего и использующегося в России, в частности, в Волгоградской области. Это растения семейства крестоцветных, в первую очередь, горчица. Поэтому далее остановимся на этом более подробнее.

\section{Изотиоцианаты}

\section{в борьбе с окислительным стрессом}

Изотиоцианаты и тиоцианаты производятся ферментативно из серосодержащих глюкозинолатов в-тиоглюкозидазами, называемыми мирозиназами [34]. Изотиоцианаты, среди прочего, играют роль аллелохимических веществ, участвуют в хранении серы, транспорте воды, термостойкости, устьичной регуляции, апоптозе, ингибировании роста и передаче сигналов [39].

В растениях семейства крестоцветных содержится большое количество глюкозинолаты, поэтому эти растения можно использовать для борьбы с вредителями или патогенами, переносимыми почвой, а также для борьбы с сорняками. Известно, что прорастание семян можно отсрочить и даже предотвратить с помощью изотиоцианатов [39].
Интересен механизм защиты от стресca у крестоцветных. У Brassicaceae (крестоцветные) повреждение тканей приводит в действие так называемую «бомбу с горчичным маслом», то есть активирует разложение глюкозинолатов мирозиназами, что приводит к быстрому накоплению изотиоцианатов в месте повреждения. Изотиоцианаты представляют собой реактивные электрофильные соединения, которые ковалентно связываются с тиолами в белках и глутатионе, и этот процесс не только токсичен для травоядных животных и микробов, но также может вызывать гибель клеток здоровых тканей растений. Ранее было показано, что субтоксичные концентрации изотиоцианата могут вызывать репрограммирование транскрипции в интактных растительных клетках [26].

Один из наиболее изученных изотиоцианатов - сульфорафан - цитотоксичен в отношении бактерий, грибов, нематод и насекомых [38].

Доказано, что предварительная обработка проростков субтоксичными концентрациями изотиоцианатов повышает устойчивость к воздействию токсичных уровней изотиоцианатов и, следовательно, может снизить аутотоксичность «горчичной бомбы», вызывая механизмы защиты клеток [26; 35].

Показана способность изотиоцианатов повышать устойчивость растений к действию повышенных температур [33].

Известны данные о физиологических ответах растительных организмов, обработанных различными экзогенными изотиоцианатами. Введение высоких доз каждого изотиоцианата ингибировало рост растений и вызывало сильное обесцвечивание листьев розетки. Обесцвечивание сопровождалось увеличением утечки электролитов и образованием пероксида водорода. Хотя все изотиоцианаты показали симптомы обесцвечивания, фенилизотиоцианат показал наиболее четкий результат. Низкая доза фенил-изотиоцианата (не приводящая к обесцвечиванию), усиливает накопление транскриптов глутатион-S-трансферазы в клетках. Эти результаты позволяют предположить, что введение в растения изотиоцианатов в высоких дозах оказывает гербицидный эффект, вызывая окислительный всплеск-подобный ответ, но что введение в 
более низких дозах увеличивает экспрессию специфических генов глутатион-S- редуктазы, способствуя этим улучшению защиты от окислительного стресса [30].

\section{Заключение}

Окислительный стресс представляет собой сложное химическое и физиологическое явление, которое сопровождает практически все биотические и абиотические стрессы у высших растений и развивается в результате накопления активных форм кислорода. Исследования окислительного стресса растений показали большой потенциал для создания устойчивых к стрессу культур.

Применение элиситоров позволяет повысить устойчивость сельскохозяйственных культур к заболеваниям, повысить их урожайность, а также сократить расход пестицидов и, таким образом, снизить негативное воздействие на окружающую природную среду. Все это делает элиситоры перспективными средствами для защиты растений.

В данном обзоре особое внимание было уделено изотиоцианатам. Их преимущество заключается в том, что изучены механизмы влияния изотиоцианатов на экспрессию генов, что позволяет относительно точно спрогнозировать действие этого элиситора на растительный организм. Также, изотиоцианаты не являются токсичными для растительноядных животных, в том числе для человека, поэтому не требуют соблюдения особых мер предосторожности. Еще одно преимущество изотиоцианатов - это доступность и дешевизна сырья для их получения и относительно простой способ выделения. Поэтому дальнейшее исследования по разработке новых комплексных препаратов для защиты растений, содержащих изотиоцианаты является актуальным направлением.

\section{СПИСОК ЛИТЕРАТУРЫ}

1. Абилова, Г. А. Влияние салициловой кислоты на формирование окислительного стресса, индуцированного $\mathrm{CdSO}_{4}$ в проростках пшеницы сорта «Краснодарская 99» / Г. А. Абилова // Известия вузов. Прикладная химия и биотехнология. $-2018 .-$ T. 10, № 3. - C. 55-60. - DOI: https://doi.org/.org/ 10.21285/2227-2925-2018-8-3-55-60.
2. Аветисян, Г. А. Аномалии ранних стадий развития Erysiphe graminis tritici при окислительном стрессе / Г. А. Аветисян, Т. В. Аветисян // Вестник Московского университета. Серия 16, Биология. -2017 . - Т. 72, №2. - С. 70-74.

3. Биоантиоксиданты (часть 1) / С. В. Гудков, В. И. Брусков, А. В. Куликов [и др.] // Альманах клинической медицины. - 2014. - № 31. - С. 61-65. DOI: https://doi.org/10.18786/2072-0505-2014-31-61-65.

4. Выделение и очистка супероксиддисмутазы из культивируемых растительных клеток / Н.В. Кириллова, О. М. Спасенкова, Н. С. Пивоварова [и др.] // Бутлеровские сообщения. - 2018. № 7. - C. 126-134. - DOI: https://doi.org/10.37952/ ROI-jbc-01/18-55-7-126.

5. Еникеев, А. Р. Протекторная и регуляторная роль аскорбиновой кислоты при действии тяжелых металлов на растения пшеницы / А. Р. Еникеев, И. Ю. Усманов, З. Ф. Рахманкулова // Вестник Башкирского университета. - 2013. - № 1. - С. 63-66.

6. Зимина, Ю. А. Применение биопрепаратов на основе хитозана в сельском хозяйстве / Ю. А. Зимина, Г. А. Срослова, М. В. Постнова // Природные системы и ресурсы. - 2018. - Т. 8, № 3. - C. 22-28. - DOI: https://doi.org/10.15688/ nsr.jvolsu.2018.3.3.

7. Карпун, Н. Н. Механизмы формирования неспецифического индуцированного иммунитета у растений при биогенном стрессе / Н. Н. Карпун, Э. Б. Янушевская, Е. В. Михайлова // Сельскохозяйственная биология. -2015 . - № 5. - С. 540-549. DOI: https://doi.org/10.31676/2073-4948-2018-53-189-196.

8. Кекало, А. Ю. Технологии защиты яровой пшеницы от фитопатогенов / А. Ю. Кекало, В. В. Немченко // Аграрный вестник Урала. - 2017. № 4. - C. 26-30.

9. Коломиец, Э. И. Биопестициды: эффективны и экологичны / Э. И. Коломиец // Наука и инновации. -2011. - № 97. - С. 11-13.

10. Колупаев, Ю. Е. Стресспротекторные эффекты салициловой кислоты и ее структурных аналогов / Ю. Е. Колупаев, Т. О. Ястреб // Физиология и биохимия культурных растений. - 2013. - Т. 45, № 2. - C. 113-126.

11. Куликов, С. Н. Роль структуры в элиситорной активности хитозана / С. Н. Куликов, В. П. Варламов // Ученые записки Казанского университета. Серия: Естественные науки. - 2008. - Т. 150, № 2.C. $43-58$.

12. Макаров, М. Р. Химические средства борьбы с некоторыми болезнями на посевах озимой пшеницы / М. Р. Макаров // Бюллетень науки и практики. -2019. - № 1. - С. 212-216.

13. Метод определения активности каталазы / М. А. Королюк, Л. И., Иванова, И. Г. Майорова [и др.] // Лабораторное дело. - 1988. - № 1. - С. 16-19. 


\section{ЭкологИя И БИоЛогия}

14. Меньщикова, Е. Б. Современные подходы при анализе окислительного стресса, или как измерить неизмеримое / Е. Б. Меньщикова, Н. К. Зенков // Acta Biomedica Scientifica. - 2016. - T. 1, № 3-2. C. 174-180. - DOI: https://doi.org/10.12737/article 590823 a565aa50.41723117.

15. Молекулярные механизмы окислительного стресса / О. А. Гребенчиков, Т. С. Забелина, Ж. С. Филипповская [и др.] // Вестник интенсивной терапии имени А. И. Салтанова. - 2016. - № 3. C. $13-21$.

16. Повышение редокс-активности растений как тест-реакция на загрязнение почв / О. 3. Еремченко, О. А. Четина, И. Е. Шестаков [и др.] // Вестник тамбовского университета. Серия: Естественные и технические науки. - 2014. - № 5. - С. 1285-1288.

17. Пожилова, Е. В. Активные формы кислорода в физиологии и патологии клетки / Е. В. Пожилова, В. Е. Новико, О. С. Левченкова // Вестник Смоленской государственной медицинской академии. 2015. - № 2. - С. 13-22.

18. Соболева, О. М. Роль ризосферных бактерий в повышении экологизации агроценозов / О. М. Соболева // Достижения науки и техники агропромышленного комплекса. - 2018. - № 5. C. $19-22$

19. Способ получения хитозана : патент на изобретение RU 2539933 C2 / Лябин М. П., Новочадов В. В., Семенов П. С. ; Федер. гос. авт. образоват. учреждение «Волгогр. гос. ун-т» ; заявл. 30.03.2012 ; опубл. 27.01.2015.

20. Физиологические эффекты действия на растения фунгицидов триазольной природы / Т. П. Побежимова, А. В. Корсукова, Н. В. Дорофеев [и др.] // Известия вузов. Прикладная химия и биотехнология. - 2019. - Т. 9, № 3. - С. 461-476. - DOI: https:// doi.org/10.21285/2227-2925-2019-9-3-461-476.

21. Яблонская, Е. К. Применение экзогенных элиситоров в сельском хозяйстве / Е. К. Яблонская // Научный журнал Кубанского государственного аграрного университета. - 2015. -№ 109.- С. 1247-1263.

22. Allyl-isothiocyanate treatment induces a complex transcriptional reprogramming including heat stress, oxidative stress and plant defence responses in Arabidopsis thaliana / R. Kissen, A. Overby, P. Winge [etal.]// BMCGenomics. - 2016. - Vol. 17, № 1. -P. 740. DOI: https://doi.org/10.1186/s12864-016-3039-x.

23. Analytical approaches to the diagnosis and treatment of aging and aging-related disease: redox status and proteomics / A. Grazianoa, I. Montea, L. Maiolinoa [et al.] // Free Radical Research. - 2015. Vol. 49, № 5. - P. 511-524. - DOI: https://dx.doi.org/ 10.3389\%2Ffpls.2015.01105.

24. Angelova, Z. Elicitation of plants / Z. Angelova, S. Georgiev, W. Roos // Biotechnology \& Biotechnological Equipment. -2006. -Vol. 20.-P. 72-83.
25. Baenas, N. Elicitation: a tool for enriching the bioactive composition of foods / N. Baenas, C. GarcнаViguera, D. A. Moreno // Molecules. - 2014. - Vol.19, № 9. - P. 13541-13563. DOI: https://doi.org/10.3390/ molecules190913541.

26. Chemical Priming by Isothiocyanates Protects Against Intoxication by Products of the Mustard Oil Bomb / E. Ferber, J. Gerhards, M. Sauer [et al.] // Frontiers in Plant Sciense - 2020. - № 11.P. 887. - DOI: https://doi.org/10.3389/fpls.2020.00887.

27. Cold acclimation induces freezing tolerance via antioxidative enzymes, proline metabolism and gene expression changes in two chrysanthemum species / Y. Chen, J. Jiang, Q. Chang [et al.] // Molecular Biology Reports - 2014. - № 41. - P. 815-822. - DOI: https://doi.org/10.1007/s11033-013-2921-8.

28. Demidchik, V. Mechanisms of oxidative stress in plants: From classical chemistry to cell biology / V. Demidchik // Environmental and Experimental Botany. - 2015. - Vol. 109. - P. 212-228. - DOI: https:// doi.org/10.1016/j.envexpbot.2014.06.021.

29. Evaluation of the Effect of oxidative stress on roots of red beet ( Beta vulgaris L. ) / E. V. Kolesnikova, N. V. Ozolina, V. N. Nurminsky [et al.] // Journal of Stress Physiology \& Biochemistry. - 2014. - № 4.

30. Exogenously applied isothiocyanates enhance glutathione S-transferase expression in Arabidopsis but act as herbicides at higher concentrations / H. Masakazu, Y. Yukie, T. Kyoko [et al.] // Journal of Plant Physiology. - 2010. - Vol. 167, № 8. - P. 643-649. - DOI: https://doi.org/10.1016/ j.jplph.2009.11.006.

31. Fatma, P. K. The effects of oxidative stress on phenolic composition and antioxidant metabolism in callus culture of common daisy / P. K. Fatma, S. C. Gunce, U. T. Arzu // African Journal of Traditional, Complementary and Alternative Medicine. - 2016. - № 3. - P. 34 41. DOI: https://doi.org/10.21010/ajtcam.v13i4.6.

32. Futrell, J. H. Development of tandem mass spectrometry: one perspective / J. H. Futrell // Int. J. of Mass Spectrom. - 2000. - № 200. - P. 495-508.

33. Hara, M. Administration of isothiocyanates enhances heat tolerance in Arabidopsis thaliana / M. Hara, A. Harazaki, K. Tabata // Plant Growth Regulation. - 2013. - Vol. 69, № 1. - P. 71-77. - DOI: https://doi.org/ 10.1007/s10725-012-9748-5.

34. Hopkins, R. J. Role of glucosinolates in insectplant relationships and multitrophic interactions / R. J. Hopkins, N. M. van Dam, J. J. A. van Loon // Annual Review of Entomology. - 2009. - № 54. P. 57-83. - DOI: https://doi.org/10.1146/annurev.ento. 54.110807.090623.

35. Ho, T. T. Methyl Jasmonate Induced Oxidative Stress and Accumulation of Secondary Metabolites in Plant Cell and Organ Cultures / T. T. Ho, H. N. Murthy, S.Y. Park // International Journal of 
Molecular Sciences. - 2020. - Vol. 21, № 3. - P. 716. DOI: https://doi.org/10.3390/ijms21030716.

36. Mazid, M. Role of secondary metabolites in defense mechanisms of plants / M. Mazid, T.A. Khan, F. Mohammad // Biology and Medicine. - 2011. № 3. - P. 232-249.

37. Noctor, G. The metabolomics of oxidative stress / G. Noctor, C. Lelarge-Trouverie, A. Mhamdi // Phytochemistry. - 2015. - № 112. - P. 33-53. - DOI: https://doi.org/10.1016/j.phytochem.2014.09.002.

38. Oxidative Stress and Heavy Metals in Plants / R. Fryzova, M. Pohanka, P. Martinkova [et al.] // Reviews of Environmental Contamination and Toxicology. - 2018. - № 245. - P. 129-156. - DOI: https:// doi.org/10.1007/398_2017_7.

39. Physiology and cellular mechanisms of isothiocyanates and other glucosinolate degradation products in plants / A. M. Bones, M. Hara, J. T. Rossiter [et al.] // Frontiers in Plant Science. - 2015. - № 9. P. 1105. -DOI: https://doi.org/ 10.3389/fpls.2015.01105.

40. Plant salt-tolerance mechanism: A review / W. Liang, X. Ma, P. Wan [et al.]. // Biochemical and Biophysical Research Communication.-2018. -Vol. 495, № 1. - P. 286-291. - DOI: https://doi.org/10.1016/ j.bbrc.2017.11.043.

41. Tholey, A. Ionic (liquid) matrices for matrixassisted laser desorption/ionization mass spectrometryapplications and perspectives / A. Tholey E. Heinzle // Analytical Bioanalytical Chemistry.-2006. - Vol. 386, № 1. - P. 24-37. - DOI: https://doi.org/10.1007/s00216006-0600-5.

42. Yang, Y. Unraveling salt stress signaling in plants / Y. Yang, Y. Guo // Journaj of Integrative Plant Biology. - 2018. - Vol. 60, № 9. - P. 796-804. - DOI: https://doi.org/ 10.1111/jipb.12689.

\section{REFERENCES}

1. Abilova, G. A. Vliyanie salicilovoj kisloty na formirovanie okislitelnogo stressa, indutsyrovannogo CdSO4 v prorostkakh pshenicy sorta «Krasnodarskaya 99» [The effect of salicylic acid on the formation of oxidative stress induced by $\mathrm{CdSO}_{4}$ in wheat seedlings of the Krasnodarskaya 99 variety]. Izvestiya vuzov. Prikladnaya khimiya i biotekhnologiya [Proceedings of universities. Applied chemistry and biotechnology], 2018, vol. 10, no. 3, pp. 55-60. DOI: https://doi.org/ .org/10.21285/2227-2925-2018-8-3-55-60.

2. Avetisjan, G. A., Avetisjan T. V. Anomalii rannih stadij razvitiya Erysiphe graminis tritici pri okislitelnom stresse [Anomalies of the early stages of development of Erysiphe graminis tritici under oxidative stress]. Vestnik Moskovskogo universiteta. Seriya 16: Biologiya [Moscow University Bulletin. Series 16: Biology], 2017, vol. 72, no. 2, pp. 70-74.
3. Gudkov S.V., Bruskov V.I., Kulikov A.V. et al. Bioantioksidanty (chast 1) [Bioantioxidants (part 1)]. Al'manah klinicheskoj mediciny [Almanac of Clinical Medicine], 2014, no. 31, pp. 61-65. DOI: https:// doi.org/10.18786/2072-0505-2014-31-61-65.

4. Kirillova N. V., Spasenkova O. M., Pivovarova N. S. et al. Vydelenie i ochistka superoksiddismutazy iz kultiviruemykh rastitelnykh kletok [Isolation and purification of superoxide dismutase from cultured plant cells]. Butlerovskie soobshheniya [Butlerov messages], 2018, no. 7, pp. 126-134. DOI: https:// doi.org/10.37952/ROI-jbc-01/18-55-7-126.

5. EnikeevA.R. Usmanov I.Ju., Rahmankulova Z.F. Protektornaya i regulyatornaya rol askorbinovoj kisloty pri dejstvii tyazhelykh metallov na rasteniya pshenicy [Protective and regulatory role of ascorbic acid in the action of heavy metals on wheat plants]. Vestnik Bashkirskogo universiteta [Bulletin of the Bashkir University], 2013, no. 1, pp. 63-66.

6. Zimina Ju.A., Sroslova G.A., Postnova M.V. Primenenie biopreparatov na osnove khitozana v selskom hozyajstve [Application of biological products based on chitosan in agriculture]. Prirodnye sistemy $i$ resursy [Natural systems and resources], 2018, vol.8, no. 3, pp. 2228. DOI: https://doi.org/10.15688/nsr.jvolsu.2018.3.3.

7. Karpun N.N., Janushevskaja Je.B., Mihajlova E.V. Mehanizmy formirovaniya nespecificheskogo inducirovannogo immuniteta u rastenij pri biogennom stresse [Mechanisms of the formation of nonspecific induced immunity in plants under biogenic stress]. Selskokhozjajstvennaya biologiya [Agricultural biology], 2015, no. 5, pp. 540-549. DOI: https://doi.org/ 10.31676/2073-4948-2018-53-189-196.

8. Kekalo A.Ju., Nemchenko V.V. Tehnologii zashhity jarovoj pshenicy ot fitopatogenov [Technologies for protecting spring wheat from phytopathogens]. Agrarnyj vestnik Urala [Agrarian Bulletin of the Urals], 2017, no. 4, pp. 26-30.

9. Kolomiec Je. I. Biopesticidy: jeffektivny i jekologichny [Biopesticides: effective and environmentally friendly]. Nauka i innovacii [Science and innovation], 2011, no. 97, pp. 11-13.

10. Kolupaev Ju.E., Jastreb T.O. Stressprotektornye jeffekty salicilovoj kisloty i ee strukturnyh analogov [Stress-protective effects of salicylic acid and its structural analogs]. Fiziologiya $i$ biohimiya kulturnykh rastenij [Physiology and biochemistry of cultivated plants], 2013, vol. 45, no. 2, pp. 113-126.

11. Kulikov S. N., Varlamov V. P. Rol struktury v jelisitornoj aktivnosti khitozana [The role of structure in the elicitor activity of chitosan]. Uchenye zapiski Kazanskogo universiteta. Seriya: Estestvennye nauki [Scientific notes of Kazan University. Series: Natural Sciences], 2008, vol. 150, no. 2, pp. 43-58.

12. Makarov M.R. Himicheskie sredstva borby s nekotorymi boleznyami na posevakh ozimoj 
pshenicy [Chemical means of combating some diseases in winter wheat crops]. Bjulleten' nauki $i$ praktiki [Science and Practice Bulletin], 2019, no. 1, pp. 212-216.

13. Koroljuk M.A., Ivanova L.I., Majorova I.G. [et al.]. Metod opredeleniya aktivnosti katalazy [Method for determination of catalase activity]. Laboratornoe delo [Laboratory work], 1988, no. 1, pp. 16-19.

14. Men'shhikova E.B., Zenkov N.K. Sovremennye podhody pri analize okislitelnogo stressa, ili kak izmerit neizmerimoe [Modern Approaches to Analyzing Oxidative Stress, or How to Measure the Immeasurable]. Acta Biomedica Scientifica [Acta Biomedica Scientifica], 2016, vol. 1, no. 3-2, pp. 174-180. DOI: https://doi.org/10.12737/ article 590823a565aa50.41723117.

15. Grebenchikov O.A., Zabelina T.S., Filippovskaja Zh.S. [et al.] Molekuljarnye mehanizmy okislitelnogo stressa [Molecular Mechanisms of Oxidative Stress]. Vestnik intensivnoj terapii imeni A. I. Saltanova [A.I. Saltanov Intensive Care Bulletin], 2016, no. 3, pp. 13-21.

16. Eremchenko O.Z., Chetina O.A., Shestakov I.E. [et al.] Povyshenie redoks-aktivnosti rastenij kak test-reakciya na zagryaznenie pochv [Increased plant redox activity as a test response to soil pollution]. Vestnik tambovskogo universiteta. Seriya: Estestvennye i tekhnicheskie nauki [Tambov University Bulletin. Series: Natural and technical sciences], 2014, no. 5, pp. 1285-1288.

17. Pozhilova E.V., Noviko V.E., Levchenkova O.S. Aktivnye formy kisloroda $v$ fiziologii i patologii kletki [Reactive oxygen species in cell physiology and pathology], Vestnik Smolenskoj gosudarstvennoj medicinskoj akademii [Bulletin of the Smolensk State Medical Academy], 2015, no. 2, pp. 13-22.

18. Soboleva O.M. Rol rizosfernyh bakterij v povyshenii ekologizacii agrocenozov [The role of rhizosphere bacteria in increasing the ecologization of agrocenoses]. Dostizheniya nauki i tehniki agropromyshlennogo kompleksa [Achievements of science and technology of the agro-industrial complex], 2018, no. 5, pp. 19-22.

19. Ljabin M.P., Novochadov V.V., Semenov P.S. Sposob polucheniya khitozana [Method for producing chitosan] patent na izobretenie RUS 253993330.03 .2012 [patent for invention RUS 2539933 03/30/2012].

20. Pobezhimova T.P., Korsukova A.V., Dorofeev N.V. et al. Fiziologicheskie jeffekty dejstviya na rasteniya fungicidov triazolnoj prirody [Physiological Effects of Triazole Fungicides on Plants]. Izvestiya vuzov. Prikladnaya khimiya $i$ biotekhnologiya [Proceedings of universities. Applied chemistry and biotechnology], 2019, vol. 9, no. 3. pp. 461-476. DOI: https://doi.org/10.21285/2227-29252019-9-3-461-476.

21. Jablonskaja E. K. Primenenie ekzogennykh elisitorov v selskom khozyajstve [The use of exogenous elicitors in agriculture]. Nauchnyj zhurnal Kubanskogo gosudarstvennogo agrarnogo universiteta [Scientific journal of the Kuban State Agrarian University], 2015, no. 109, pp. 1247-1263.

22. Kissen R., Overby A., Winge P. [et al.]. Allylisothiocyanate treatment induces a complex transcriptional reprogramming including heat stress, oxidative stress and plant defence responses in Arabidopsis thaliana. BMC Genomics, 2016, vol. 17, no. 1, pp.740. DOI: https://doi.org/10.1186/s12864-0163039-x.

23. Grazianoa A., Montea I., Maiolinoa L. [et al.]. Analytical approaches to the diagnosis and treatment of aging and aging-related disease: redox status and proteomics. Free Radical Research, 2015, vol. 49, no. 5, pp. 511-524. DOI: https://dx.doi.org/10.3389\%2Ffpls. 2015.01105.

24. Angelova Z., Georgiev S., Roos W. Elicitation of plants. Biotechnology\& Biotechnological Equipment, 2006, vol. 20, pp. 72-83.

25. Baenas N., Garcha-Viguera C., Moreno D. A. Elicitation: a tool for enriching the bioactive composition of foods. Molecules, 2014, vol.19, no. 9, pp.13541-13563. DOI: https://doi.org/10.3390/ molecules190913541.

26. Ferber E., Gerhards J., Sauer M. [et al.] Chemical Priming by Isothiocyanates Protects Against Intoxication by Products of the Mustard Oil Bomb. Frontiers in Plant Sciense, 2020, no. 11, pp. 887. DOI: https://doi.org/10.3389/fpls.2020.00887.

27. Chen Y., Jiang J., Chang Q. et al. Cold acclimation induces freezing tolerance via antioxidative enzymes, proline metabolism and gene expression changes in two chrysanthemum species. Molecular Biology Reports, 2014, no. 41, pp. 815-822. DOI: https:// doi.org/10.1007/s1 1033-013-2921-8.

28. Demidchik V. Mechanisms of oxidative stress in plants: From classical chemistry to cell biology. Environmental and Experimental Botany, 2015, vol. 109, pp. 212-228. DOI: https://doi.org/10.1016/ j.envexpbot.2014.06.021.

29. KolesnikovaE. V., Ozolina N. V., Nurminsky V.N. [et al.] Evaluation of the Effect of oxidative stress on roots of red beet (Beta vulgaris L.). Journal of Stress Physiology \& Biochemistry, 2014, no. 4.

30. Masakazu H., Yukie Y., Kyoko T. et al. Exogenously applied isothiocyanates enhance glutathione S-transferase expression in Arabidopsis but act as herbicides at higher concentrations. Journal of Plant Physiology, 2010, vol. 167, no. 8, pp. 643-649. DOI: https://doi.org/10.1016/j.jplph.2009.11.006. 
31. Fatma P.K., Gunce S.C., Arzu U.T. The effects of oxidative stress on phenolic composition and antioxidant metabolism in callus culture of common daisy. African Journal of Traditional, Complementary and Alternative Medicine, 2016, no. 3, pp, 34-41. DOI: https://doi.org/10.21010/ajtcam.v13i4.6.

32. Futrell J.H. Development of tandem mass spectrometry: one perspective. International Journal of Mass Spectrometry, 2000, no. 200, pp. 495-508.

33. Hara M., Harazaki A., Tabata K. Administration of isothiocyanates enhances heat tolerance in Arabidopsis thaliana. Plant Growth Regulation, 2013, vol. 69, no. 1, pp. 71-77. DOI: https://doi.org/ 10.1007/ s10725-012-9748-5.

34. Hopkins R.J., van Dam N.M., van Loon J.J. A. Role of glucosinolates in insectplant relationships and multitrophic interactions. Annual Review of Entomology, 2009, no. 54, pp. 57-83. DOI: https:// doi.org/10.1146/annurev.ento.54.110807.090623.

35. Ho T.T., Murthy H. N., Park S.Y. Methyl jasmonate induced oxidative stress and accumulation of secondary metabolites in plant cell and organ cultures. International Journal of Molecular Sciences, 2020, vol. 21, no. 3. p. 716. DOI: https:// doi.org/10.3390/ijms21030716.

36. Mazid M., Khan T.A., Mohammad F. Role of secondary metabolites in defense mechanisms of plants. Biology and Medicine, 2011, no. 3, pp. 232-249.
37. Noctor G., Lelarge-Trouverie C., Mhamdi A. The metabolomics of oxidative stress. Phytochemistry, 2015, no. 112, pp. 33-53. DOI: https://doi.org/10.1016/ j.phytochem.2014.09.002.

38. Fryzova R., Pohanka M., Martinkova P. [et al.]. Oxidative stress and heavy metals in plants. Reviews of environmental. Contamination and Toxicology, 2018, no. 245, pp. 129-156. DOI: https://doi.org/10.1007/ 39820177.

39. Bones A.M., Hara M., Rossiter J.T. [et al.]. Physiology and cellular mechanisms of isothiocyanates and other glucosinolate degradation products in plants. Frontiers in Plant Science, 2015, no. 9, p. 1105. DOI: https://doi.org/ 10.3389/fpls.2015.01105.

40. Liang W., Ma X., Wan P. [et al.] Plant salttolerance mechanism: A review. Biochemical and Biophysical Research Communication, 2018, vol. 495, no. 1, pp. 286-291. DOI: https://doi.org/10.1016/ j.bbrc.2017.11.043.

41. Tholey A., Heinzle E. Ionic (liquid) matrices for matrix-assisted laser desorption/ionization mass spectrometry-applications and perspectives. Analytical Bioanalytical Chemistry, 2006, vol. 386, no. 1, pp. 2437. DOI: https://doi.org/10.1007/s00216-006-0600-5.

42. Yang, Y., Guo Y. Unraveling salt stress signaling in plants. Journaj of Integrative Plant Biology, 2018, vol. 60, no. 9, pp. 796-804. DOI: https:// doi.org/ 10.1111/jipb.12689.

\section{Information About the Authors}

Ekaterina V. Khozeeva, Student, Department of Bioengineering and Bioinformatics, Volgograd State University, Prosp. Universitetsky, 100, 400062 Volgograd, Russian Federation, bib-81_643425@volsu.ru

Yuliya A. Zimina, Candidate of Sciences (Chemistry), Associate Professor, Department of Bioengineering and Bioinformatics, Volgograd State University, Prosp. Universitetsky, 100, 400062 Volgograd, Russian Federation, zimina.yuliya@volsu.ru

Galina A. Sroslova, Candidate of Sciences (Biology), Associate Professor, Department of Bioengineering and Bioinformatics, Volgograd State University, Prosp. Universitetsky, 100, 400062 Volgograd, Russian Federation, sroslova.galina@volsu.ru

\section{Информация об авторах}

Екатерина Владимировна Хозеева, студент кафедры биоинженерии и биоинформатики, Волгоградский государственный университет, просп. Университетский, 100, 400062 г. Волгоград, Российская Федерация, bib-81_643425@volsu.ru

Юлия Александровна Зимина, кандидат химических наук, доцент кафедры биоинженерии и биоинформатики, Волгоградский государственный университет, просп. Университетский, 100, 400062 г. Волгоград, Российская Федерация, zimina.yuliya@volsu.ru

Галина Алексеевна Срослова, кандидат биологических наук, доцент кафедры биоинженерии и биоинформатики, Волгоградский государственный университет, просп. Университетский, 100, 400062 г. Волгоград, Российская Федерация, sroslova.galina@volsu.ru 